\title{
Nitrogen deposition and soil carbon content affect nitrogen mineralization during primary succession in acid inland drift sand vegetation
}

\author{
Laurens B. Sparrius • Annemieke M. Kooijman
}

Received: 15 February 2012 / Accepted: 25 June 2012 / Published online: 13 July 2012

(C) The Author(s) 2012. This article is published with open access at Springerlink.com

\begin{abstract}
Background and aims Two inland dunes in the Netherlands receiving low (24) and high (41 $\left.\mathrm{kg} \mathrm{N} \mathrm{ha}^{-1} \mathrm{yr}^{-1}\right)$ nitrogen $(\mathrm{N})$ deposition were compared for $\mathrm{N}$ dynamics and microbial activity to investigate the potential effect of $\mathrm{N}$ on succession rate of the vegetation and loss of pioneer habitats.

Methods Primary succession stages were sampled, including bare sand, and vegetation dominated by Polytrichum piliferum, Campylopus introflexus, lichens and grasses respectively, representing a series of vegetation types in undisturbed drift sand sites with succession starting on bare sand containing virtually no organic matter. Microbial characteristics and potential $\mathrm{N}$ mineralization were analysed in a laboratory experiment.

Results Organic matter accumulated during succession, resulting in a lower $\mathrm{pH}$ and in higher microbial biomass (bacteria and fungi), respiration and net $\mathrm{N}$ mineralization. The increase in respiration and $\mathrm{N}$ mineralization was largely due to the development of an ectorganic layer in the middle stages of succession. The observed effects of $\mathrm{N}$ deposition were (1) decrease of microbial biomass, (2) higher net $\mathrm{N}$ mineralization per $\mathrm{m}^{2}$, (3)
\end{abstract}

Responsible Editor: Hans Lambers.

L. B. Sparrius $(\triangle) \cdot$ A. M. Kooijman

Institute for Biodiversity and Ecosystem Dynamics,

University of Amsterdam,

P.O. Box 942481090 GE Amsterdam, The Netherlands

e-mail: 1.b.sparrius@uva.nl higher levels of free nitrogen in the soil, and (4) a higher microbial N:P ratio.

Conclusions Elevated $\mathrm{N}$ deposition leads to higher $\mathrm{N}$ availability which may cause accelerated succession.

Keywords Corynephorus canescens $\cdot$ Soil development $\cdot$ Microbial biomass $\cdot \mathrm{C}: \mathrm{N}$ ratio $\cdot \mathrm{N}: \mathrm{P}$ ratio

\section{Introduction}

Plant growth in semi-arid acid sand ecosystems is, like in most pioneer environments, nitrogen limited (van Mierlo et al. 2000). During succession, N mineralization may become higher due to the increase of soil organic matter (Gerlach et al. 1994). The increase of $\mathrm{N}$ availability is regarded as one of the most important driving factors controlling species composition during primary succession in nutrient-poor ecosystems (Crocker and Major 1955; Berendse 1990, 1998; Schulze et al. 1995). Apart from an increase of the $\mathrm{N}$ mineralization due to an increase in soil organic content during succession, regionally higher levels of $\mathrm{N}$ deposition may cause higher $\mathrm{N}$ availability, resulting in a higher succession rate (Bobbink et al. 1998). The inland dune environment does depend much on atmospheric deposition of $\mathrm{N}$ as nitrogen fixation is very low or absent due the calciumpoor substrate (Sparrius and Kooijman 2011; Nijssen et al. 2011; Sparrius et al. 2012).

In acid inland dunes, primary succession starts with bare sand, which may contain scattered Corynephorus 
canescens plants. In the second stage, when wind dynamics decreased and sand has stabilized, the space between the grass tussocks is filled with Polytrichum piliferum moss mats, consisting of sparse shoots in bare sand connected with a dense rhizoid layer belowground (Bowden 1991). Lichen species start to colonize the Polytrichum mats in the subsequent stage. However, at present, $P$. piliferum mats are often colonized by the invasive bryophyte species Campylopus introflexus, especially in sites with high $\mathrm{N}$ deposition (Hassel and Söderström 2005; Sparrius and Kooijman 2011). In the last stage grasses gradually become dominant and finally Calluna vulgaris (L.) Hull establishes (Hasse 2005). During succession on bare soil, initially a thin $A_{h}$ horizont is formed by Polytrichum rhizoids. In later stages, the organic topsoil is supplemented with roots of tufted and stoloniferous grasses and may become up to $12 \mathrm{~cm}$ thick before Calluna settles (Sparrius et al. 2012).

The first question is how $\mathrm{N}$ mineralization and nitrification in the mineral topsoil and the ectorganic layer change during succession in drift sands. In most early succession stages, the mineral topsoil is the most important soil compartment. In Campylopus introflexus dominated vegetations, however, but also in lichen-dominated vegetation, an ectorganic layer is formed by the basal part of the mat-forming acrocarpous moss plant. As bryophytes and lichens have no root system, the ectorganic layer could provide a substrate for mineralization and interception of atmospheric deposition, which is readily available for the upper living part of the plant (Cornelissen et al. 2001; Crittenden 1991; Sipman 1978).

The second question is how atmospheric $\mathrm{N}$ deposition is related to $\mathrm{N}$ dynamics. High $\mathrm{N}$ deposition may result in higher $\mathrm{N}$ availability to the vegetation directly, but also indirectly, via higher $\mathrm{N}$ mineralization, which can be caused by presence of organic matter with a low C:N ratio (Swift et al. 1979) or direct uptake of $\mathrm{N}$ by micro-organisms. This hypothesis is tested by comparing similar succession stages in inland dunes with rather low and high $\mathrm{N}$ deposition.

\section{Materials and methods}

Study sites

Succession stages were compared in two inland dune reserves: Aekinge $\left(52.924^{\circ} \mathrm{N}, 6.294^{\circ} \mathrm{E}\right)$, a site with relatively low $\mathrm{N}$ deposition, located in the North of The Netherlands, and Wekerom $\left(52.100^{\circ} \mathrm{N}, 5.679^{\circ} \mathrm{E}\right)$, a site with high $\mathrm{N}$ deposition $150 \mathrm{~km}$ South, in the central part of the country. Both areas are similar in climate and size and contain active drift sands, but also restored drift sands where trees and undergrowth vegetation were removed.

The sites mainly differ in the amount of atmospheric nitrogen deposition, predominantly ammonia originating from agricultural sources. Nitrogen deposition has been measured from June 2008 till May 2009, by sampling with monthly replaced ammonia diffusion tubes (Sparrius 2011). Total deposition can be calculated from the ammonia air concentration with a formula developed by Cape et al. (2009) assuming a low particle deposition velocity of $15 \mathrm{~mm} \mathrm{~s}^{-1}$. This resulted in an average deposition of $24 \mathrm{~kg} \mathrm{~N}^{-1} \mathrm{yr}^{-1}$ in Aekinge $(5.8 \mu \mathrm{g}$ $\left.\mathrm{NH}_{3} \mathrm{~m}^{-3}\right)$ and $41 \mathrm{~kg} \mathrm{~N}^{-1} \mathrm{yr}^{-1}$ in Wekerom $(9.7 \mu \mathrm{g}$ $\mathrm{NH}_{3} \mathrm{~m}^{-3}$ ), which agrees with modelled deposition values (Eerens and van Dam 2001; van Jaarsveld 2004; de Haan et al. 2008). Precipitation in both sites is around $800 \mathrm{~mm} \mathrm{yr}^{-1}$ (Sluijter and Nellestijn 2009).

In both areas, a succession sere on formerly active drift sand dunes was sampled. We selected $1 \times 1 \mathrm{~m}$ plots over a gradient of succession stages varying from 0 to circa 20 years in age since vegetation development started (Sparrius 2011): (1) bare sand, (2) mats of Polytrichum piliferum, (3) mats of Campylopus introflexus, (4) pioneer vegetation dominated by lichens (Cladonia spp.) and (5) vegetation dominated by grasses, which are described in Table 1 . The classification of succession stages is adapted from Hasse (2005). The species composition of the stages is further described by Sparrius et al. (2012). Succession stages, except for bare sand, are named after their dominant ( $>90 \%$ cover) species or species group. For each succession stage in a particular area, four replicate plots were selected according to a stratified random procedure. All plots were similar with respect to slope and orientation. Within a particular succession stage, soil depth was similar between replicates. Nomenclature of species follows Aptroot et al. (2004) for lichens, Siebel and During (2006) for bryophytes and van der Meijden (2005) for vascular plants.

\section{Sampling}

Fresh, slightly humid soil samples were collected in the last week of October 2007 during dry weather and maximum temperatures around $10{ }^{\circ} \mathrm{C}$. The upper $5 \mathrm{~cm}$ 
of the mineral topsoil was collected by combining three subsamples taken with metal cylinders of $100 \mathrm{~cm}^{3}$ and stored for 4 to 6 days at $4{ }^{\circ} \mathrm{C}$ before further analysis.

In case of the Campylopus and lichen-dominated stages, in each plot the ectorganic layer was also sampled. This was done by collecting the moss or lichen mats in $25 \times 25 \mathrm{~cm}$ squares and removing the living parts from the basal ectorganic layer in the laboratory immediately after collection. In the case of lichens, dry weight of the ectorganic layer was determined for all four replicates separately, but because little material was available, this was combined into one sample in the incubation experiment.

\section{Laboratory analysis}

Fresh samples were gently homogenized and weighed. A subsample was dried at $60{ }^{\circ} \mathrm{C}$ for $48 \mathrm{~h}$ to determine moisture content. Total $\mathrm{C}$ and $\mathrm{N}$ were measured in a Fisher EA1110 CNS analyser (Westerman 1990). Nitrate, ammonium and phosphate were measured in extracts of fresh soil in $50 \mathrm{ml}$ of $0.5 \mathrm{M} \mathrm{K}_{2} \mathrm{SO}_{4}$ solution (1:2.5), using an Auto Analyzer III (Bran + Luebbe). In these extracts, element concentrations $(\mathrm{Ca}, \mathrm{Fe}, \mathrm{Na}, \mathrm{Mg}$, and $\mathrm{Al}$ ) were measured with an inductively coupled plasma analyser (ICP-OES, Fisher Iris Intrepid II).

To estimate microbial biomass (mainly bacteria and fungi) and microbial element content in fresh samples, the chloroform fumigation and extraction method was used (Brookes et al. 1982, 1985). Immediately after $24 \mathrm{~h}$ of fumigation with chloroform, element concentrations of water-soluble substances were analysed as fresh samples. The concentration of elements in the microbial biomass was calculated by subtracting the concentrations of the non-fumigated samples from the fumigated samples, representing the amount of waterextractable compounds present in living cells, as far as they could be destructed by the chloroform treatment. A few obvious outliers due to measurement errors were omitted for $\mathrm{N}: \mathrm{P}$ and $\mathrm{C}: \mathrm{N}$ ratios at very low $\mathrm{P}$ (three times) or $\mathrm{N}$ (one time) values respectively.

To estimate potential nitrogen mineralization and nitrification, a mineralization assay was made (Keeney 1980). Approximately $50 \mathrm{~g}$ of mineral topsoil or organic layer was kept for 40 days in petri dishes in the dark at room temperature. The moisture content of the samples was kept at 20-30\%, checked weekly and replenished with demineralized water when necessary.
Ammonium and nitrate concentrations were measured in fresh and incubated samples by $\mathrm{K}_{2} \mathrm{SO}_{4}$ extraction as described for fresh samples. Net $\mathrm{N}$ mineralization and nitrification were calculated, based on differences between incubated and fresh samples. $\mathrm{N}$ mineralization per unit microbial $\mathrm{C}$ was calculated using microbial $\mathrm{C}$ values at the start of the incubation experiment. Nitrification is calculated as the difference in nitrate content before and after incubation divided by the total amount of mineralized $\mathrm{N}$ during the experiment.

To estimate microbial activity, $\mathrm{CO}_{2}$ production of both fresh and incubated samples was measured at room temperature at $30 \mathrm{~min}$. intervals using gas chromatography (Kooijman et al. 2008; Tietema 1992). Mean values of respiration before and after incubation were used as an estimate for microbial activity.

Statistical analysis

Values in $\mathrm{mg} \mathrm{kg}^{-1}$ were transformed into stock values per $\mathrm{m}^{2}$ to account for decrease in bulk density during succession. $\mathrm{N}: \mathrm{P}$ and $\mathrm{C}: \mathrm{N}$ ratios were calculated in $\mathrm{g} \mathrm{g}^{-1}$, $\mathrm{NH}_{4}{ }^{+}: \mathrm{NO}_{3}{ }^{-}$ratios are molar ratios. A two-way ANOVA was applied, with stage of succession (open, Polytrichum, Campylopus, lichen-rich vegetation and grassland) and $\mathrm{N}$ deposition (low and high) as independent factors. Two-way ANOVA was applied on measured values, but due to high variation between early and later succession stages, also on log-transformed values. Differences between individual mean values were tested with lsmeans tests in SAS. Different letters in graphs indicate significant differences $(P<0.05)$ between means.

\section{Results}

Soil characteristics per succession stage

The two study areas showed similar developments during succession. In actual drift sand, organic matter built up during succession, resulting in an increase in solum depth (Table 1). As a result of soil formation, $\mathrm{pH}\left(\mathrm{H}_{2} \mathrm{O}\right)$ decreased from 5.4 to 4.3 in Aekinge (Table 2). The soil $\mathrm{C}: \mathrm{N}$ ratio varied between succession stages. Bare sand had relatively low values of 7-13, but $\mathrm{C}: \mathrm{N}$ ratios significantly $(P<0.01)$ increased to $17-18$ in stages with Polytrichum piliferum and values around 21 in Campylopus introflexus. In lichens, however, $\mathrm{C}: \mathrm{N}$ ratios 
Table 1 Description of the five succession stages analyzed in this study. The description is valid for both study areas, and for succession series in both drift sand and restored sites

\begin{tabular}{ll}
\hline Succession stage & Description \\
\hline Bare sand & Bare sand, occasionally with a c. 0.1 mm thick algal crust, \\
& between scattered plants of Corynephorus canescens \\
Polytrichum & $90-100 \%$ Polytrichum piliferum mats with scarce Corynephorus canescens tufts \\
Campylopus & $80-100 \%$ Campylopus introflexus mats, accompanied with Corynephorus canescens, \\
& Polytrichum piliferum \\
Lichens & Dominant small Cladonia spp. (e.g. C. glauca Floerke, C. macilenta Hoffm., \\
& C. ramulosa (With.) J.R. Laundon, C. strepsilis (Ach.) Vain.) on Polytrichum piliferum mats \\
Grasses & with larger Cladonia species \\
\end{tabular}

decreased again to values of 13-15. Although there was a strong difference in $\mathrm{N}$ deposition, total soil $\mathrm{N}$ content and $\mathrm{C}: \mathrm{N}$ ratio and extractable cation concentrations $(\mathrm{Ca}$, $\mathrm{Fe}, \mathrm{Na}, \mathrm{Mg}$, and $\mathrm{Al}$ ) did not show differences between the low and high $\mathrm{N}$ deposition sites and these data were not used in further analyses.

The ectorganic layer was only present in plots with Campylopus introflexus and lichens, This layer is circa four times higher in weight in Campylopus than in lichens, and had a significantly $(P=0.02)$ higher $\mathrm{C}: \mathrm{N}$ ratio of $28 \pm 3$, compared to $19 \pm 0$ in lichens. $\mathrm{C}: \mathrm{N}$ ratios of the two stages were however not different $(P=0.13)$ between the high and low $\mathrm{N}$ deposition area. Carbon content in the mineral top soil varied from circa $0.02 \mathrm{~kg} \mathrm{C} \mathrm{m}^{-2}$ in bare sand to $0.5 \mathrm{~kg} \mathrm{~m}^{-2}$ in lichen and grass stages. The ectorganic layer added circa $1 \mathrm{~kg} \mathrm{C} \mathrm{m}^{-2}$ in the Campylopus stage and $0.5 \mathrm{~kg} \mathrm{~m}^{-2}$ in the lichen stage.

Soil microbial $\mathrm{C}$ and respiration

Statistical analysis showed that microbial $\mathrm{C}$ was affected by both succession and $\mathrm{N}$ deposition. During succession the amount of microbial $\mathrm{C}$ increased (Fig. 1). The ectorganic layer of Campylopus introflexus and lichens strongly contributed to the microbial C stocks in the Campylopus and lichen succession stages. In Campylopus, this layer was two to four times higher in weight than in lichens, which is also reflected in the observed values for microbial $\mathrm{C}$. Soil microbial $\mathrm{C}$ was significantly $(P=0.03)$ higher in Aekinge, the low $\mathrm{N}$ deposition area, than in Wekerom, especially in the Campylopus and grass stages. Like microbial C, respiration (a measure of microbial activity; Fig. 1) generally increased during succession. Respiration did however not differ between Aekinge and Wekerom, except for the Campylopus stage..

\section{Nitrogen mineralization}

Net nitrogen mineralization was significantly affected by vegetation stage, and increased during succession (Fig. 2). Net nitrogen mineralization was low in open sand and stages with Polytrichum. In the latter, net $\mathrm{N}$ mineralization per unit microbe was lower than in all other stages. Nitrification in Polytrichum was very low

Table 2 Characteristics of the mineral top soil of the succession stages in the two study sites. Values are means $(n=4)$ and standard deviations between brackets. Different letters show significant differences between succession stages $(P<0.05)$

\begin{tabular}{|c|c|c|c|c|c|c|c|c|}
\hline \multirow[t]{2}{*}{ Succession stage } & \multicolumn{4}{|c|}{ Aekinge (low N deposition) } & \multicolumn{4}{|c|}{ Wekerom (high N deposition) } \\
\hline & $\mathrm{pH}\left(\mathrm{K}_{2} \mathrm{SO}_{4}\right)$ & $\mathrm{C}\left(\mathrm{g} \mathrm{m}^{-2}\right)$ & $\mathrm{N}\left(\mathrm{g} \mathrm{m}^{-2}\right)$ & $\mathrm{C}: \mathrm{N}$ ratio & $\mathrm{pH}\left(\mathrm{K}_{2} \mathrm{SO}_{4}\right)$ & $\mathrm{C}\left(\mathrm{g} \mathrm{m}^{-2}\right)$ & $N\left(\mathrm{~g} \mathrm{~m}^{-2}\right)$ & $\mathrm{C}: \mathrm{N}$ ratio \\
\hline Bare sand & $5.4(0.0) \mathrm{a}$ & $29(5) \mathrm{a}$ & $2(1) \mathrm{a}$ & $12.8(5.0) \mathrm{ab}$ & $5.3(0.1) \mathrm{a}$ & $14(0) \mathrm{a}$ & $2(1) \mathrm{a}$ & $6.7(2.4) \mathrm{a}$ \\
\hline Polytrichum & $4.8(0.0) \mathrm{b}$ & $279(23) b$ & $15(1) b$ & $17.6(1.2) \mathrm{ab}$ & $4.5(0.0) \mathrm{b}$ & $263(44) b$ & $15(3) b c$ & $18.0(3.9) \mathrm{b}$ \\
\hline Campylopus & $4.7(0.1) b$ & $259(20) b$ & $14(1) b$ & $21.2(3.0) \mathrm{ab}$ & $4.5(0.0) \mathrm{b}$ & $184(26) \mathrm{c}$ & $14(1) \mathrm{c}$ & $21.5(3.0) \mathrm{b}$ \\
\hline Lichens & $4.3(0.2) \mathrm{c}$ & $502(300) \mathrm{bc}$ & $37(17) \mathrm{c}$ & $13.2(1.1) \mathrm{a}$ & $4.2(0.0) \mathrm{c}$ & $434(48) d$ & $31(3) b$ & $14.9(1.2) b$ \\
\hline Grasses & $4.8(0.0) \mathrm{b}$ & $166(25) \mathrm{c}$ & $10(1) \mathrm{d}$ & $16.2(1.6) \mathrm{b}$ & $4.0(0.2) \mathrm{d}$ & $578(293) \mathrm{e}$ & $31(10) b$ & $17.8(3.2) b$ \\
\hline
\end{tabular}


Fig. 1 Microbial biomass and respiration under lab conditions measured in fresh soil samples in different succession stages in both study sites. Means $(n=4)$ and standard deviations (error bars) of the soil and ectorganic layer. Names of succession stages are abbreviated to the first four or five letters. Different letters mean significant differences between succession stages (lsmeans test performed on the sum of mineral soil and ectorganic layer). Significant differences between sites were found for soil microbial $\mathrm{C}$ only

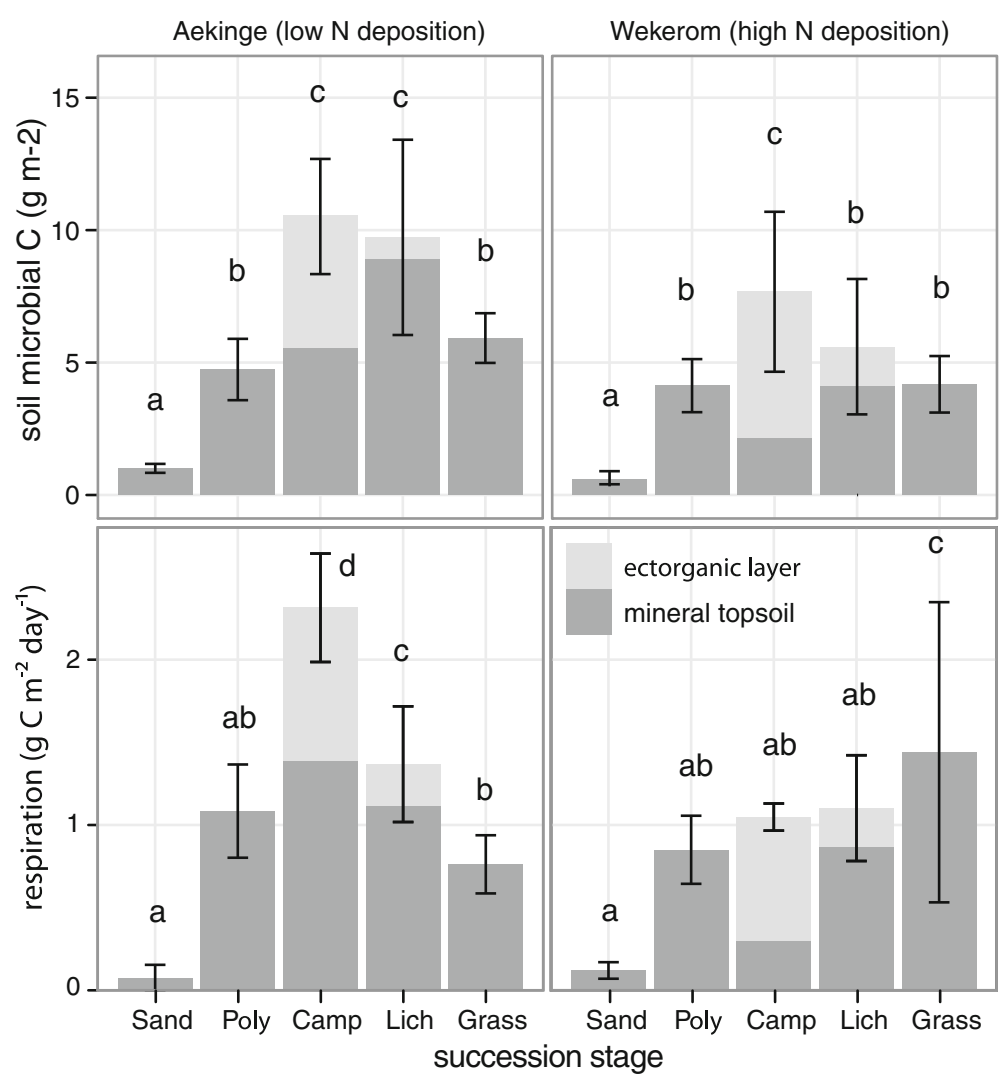

(Table 3), which further points to $\mathrm{N}$ stress. In bare sand, nitrification amounted to $53-132 \%$, and in later stages of succession, values still accounted for 44$62 \%$ of total net $\mathrm{N}$ mineralization. In later stages of succession, the contribution of the ectorganic layers to the $\mathrm{N}$ mineralization also became more important. In lichens, contribution of the ectorganic layer increased to $9-17 \%$ and in Campylopus plots even to 33-42\% of the total $\mathrm{N}$ mineralization. In addition to succession stage, net $\mathrm{N}$ mineralization was also affected by $\mathrm{N}$ deposition. Net nitrogen mineralization was slightly higher in Wekerom than in Aekinge and this difference was significant when based on log-transformed values $(P=0.049)$. Net $\mathrm{N}$ mineralization per unit microbial $\mathrm{C}$ showed even larger differences between sites with high and low $\mathrm{N}$ deposition, being generally $2-3$ times higher in Wekerom than in Aekinge $(P<0.001)$.

The amount of inorganic $\mathrm{N}$ (nitrate and ammonium) in fresh samples did not differ between vegetation types, but was significantly affected by $\mathrm{N}$ deposition (Fig. 2): ammonium concentrations were higher in Wekerom than in Aekinge $(P=0.046)$, resulting in a higher ammonium:nitrate ratio, which is, averaged for all succession stages, $2.0 \pm 1.1$ in Aekinge, and $6.0 \pm$ 5.7 in Wekerom $(P=0.06)$.

Microbial N:P and C:N ratios

Differences in $\mathrm{N}$ deposition may also be reflected in microbial $\mathrm{C}: \mathrm{N}$ and $\mathrm{N}: \mathrm{P}$ ratios (Table 4). The microbial $\mathrm{C}: \mathrm{N}$ ratio had values of 13 to 20 in Aekinge and 8 to 10 in Wekerom. Microbial N:P ratios were significantly higher in Wekerom than in Aekinge $(P=0.001)$.

\section{Discussion}

$\mathrm{N}$ mineralization and soil organic matter

Along with the succession and build-up of soil organic matter, $\mathrm{N}$ mineralization increased in both drift sand sites. The $\mathrm{N}$ mineralization was low or even negative (Aekinge) in Polytrichum piliferum mats, despite the increase in soil organic matter and microbial $\mathrm{C}$ compared to bare sand. This is reflected in the low net $\mathrm{N}$ mineralization per unit microbe, and low nitrification, 
Fig. 2 Net N mineralization and $\mathrm{N}$ mineralization per unit microbial C (soil + ectorganic layer) under lab conditions and amounts of $\mathrm{K}_{2} \mathrm{SO}_{4}$-extractable ammonium and nitrate in fresh samples of soil and ectorganic layer (Campylopus and lichen stages only) in different succession stages in both drift sand sites. Means ( $n=$ 4) and standard deviations (error bars) of the soil and ectorganic layer. Different letters are significant differences between succession stages. Names of succession stages are abbreviated to the first four or five letters (lsmeans test performed on the sum of mineral soil and ectorganic layer). All parameters showed significant differences between sites

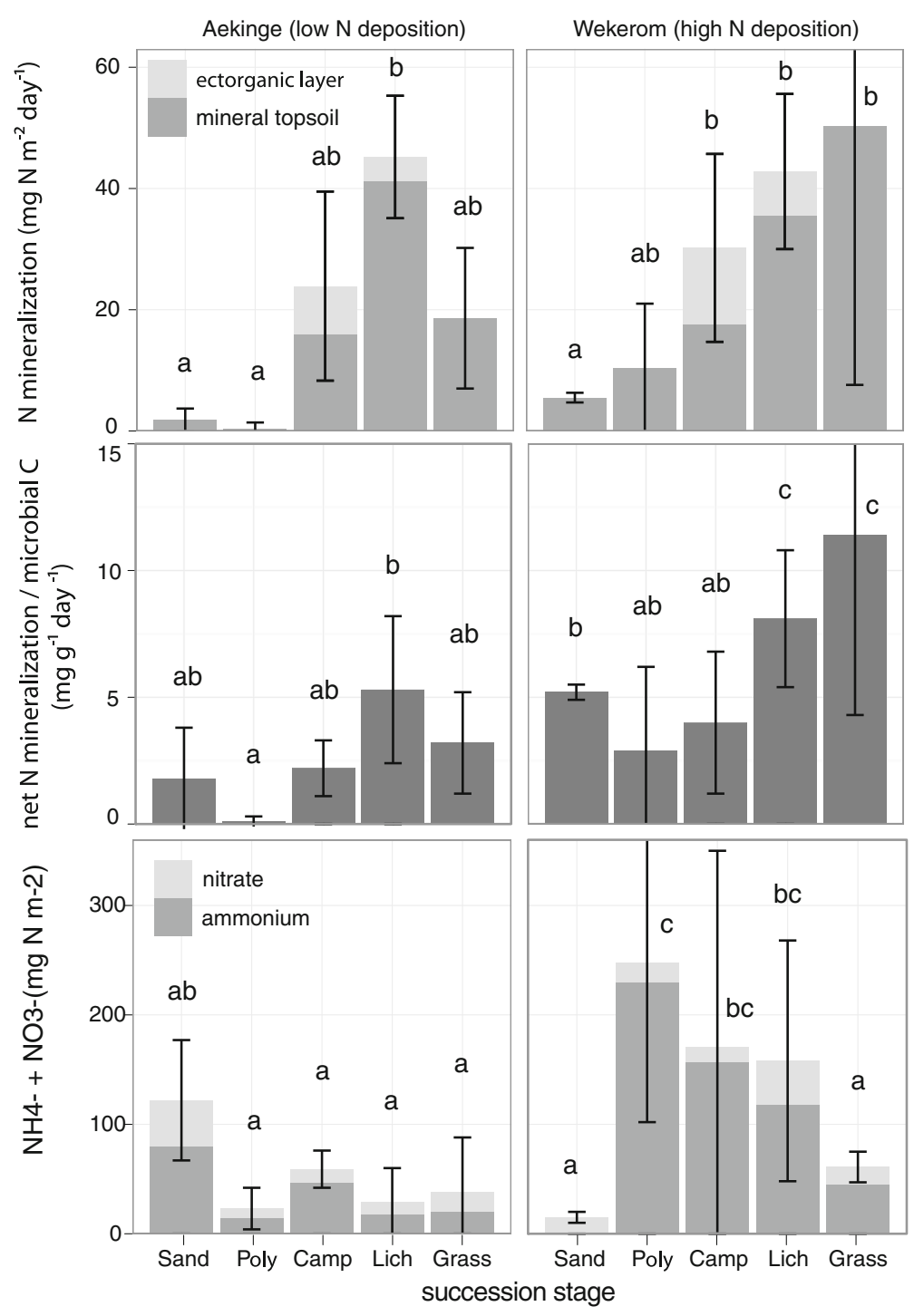

which suggests that $\mathrm{N}$ is a limiting factor in this stage of succession, even in areas with high atmospheric $\mathrm{N}$ deposition. This could perhaps be explained by the composition of the rhizoids of Polytrichum piliferum, which are the primary source of carbon in the $A_{h}$ horizon (Bowden 1991) and have a relatively high C: $\mathrm{N}$ ratio. Decomposition of organic matter with a high
$\mathrm{C}: \mathrm{N}$ ratio could therefore result in lower release of $\mathrm{N}$ by microbes (Swift et al. 1979), as compared to a substrate with a lower $\mathrm{C}: \mathrm{N}$ ratio.

The mineral soil characteristics below Campylopus introflexus mats were more or less similar to $P$. piliferum. Also, net $\mathrm{N}$ mineralization in the mineral soil was only slightly higher than in $P$. piliferum.

Table 3 Nitrification as a percentage of total $\mathrm{N}$ mineralization in incubated samples of mineral soil. Values are means and standard deviations between brackets. Different letters show significant differences between succession stages $(P<0.05)$

\begin{tabular}{|c|c|c|c|c|c|}
\hline & Bare sand & Polytrichum & Campylopus & Lichens & Grasses \\
\hline Aekinge & $53(15) \mathrm{a}$ & $-22(30) b$ & 44 (14) a & $62(9) \mathrm{a}$ & $56(27) \mathrm{a}$ \\
\hline Wekerom & $132(58) \mathrm{a}$ & $26(14) b$ & $52(16) \mathrm{c}$ & $60(13) \mathrm{c}$ & $57(20) \mathrm{c}$ \\
\hline
\end{tabular}


Table 4 Microbial C:N and N:P ratios in the soil in different succession stages in drift sand sites of both study sites with low (Aekinge) and high (Wekerom) $\mathrm{N}$ deposition. Mean values and standard deviations $(n=4)$. The difference between the two study sites was significant $(P<0.05)$ for both the C:N and N:P ratio. Values for bare sand could not be calculated due to phosphorus values below the detection limit. Different letters indicate significant differences between succession stages within a site

\begin{tabular}{|c|c|c|c|c|}
\hline & Polytrichum & Campylopus & Lichens & Grasses \\
\hline \multicolumn{5}{|c|}{ Microbial C:N ratio } \\
\hline Aekinge & $20(3) \mathrm{a}$ & 19 (1) a & $13(2) b$ & $13(2) b$ \\
\hline Wekerom & $10(2) \mathrm{a}$ & $8(2) \mathrm{a}$ & $9(4) \mathrm{a}$ & $9(2) \mathrm{a}$ \\
\hline \multicolumn{5}{|c|}{ Microbial N:P ratio } \\
\hline Aekinge & $4(1) \mathrm{a}$ & $9(2) b$ & $23(3) \mathrm{c}$ & $10(2) b$ \\
\hline Wekerom & 35 (7) a & $35(10) \mathrm{a}$ & $25(10) \mathrm{ab}$ & $16(9) b$ \\
\hline
\end{tabular}

The main difference is that in C. introflexus, $\mathrm{N}$ cycling and $\mathrm{C}$ storage for a large part take place aboveground in the moss mat itself. Due to the development of an ectorganic layer of dead moss, two times the amount of $\mathrm{C}$ and $\mathrm{N}$ can be stored aboveground as compared to the mineral soil below. The microbial biomass, respiration and $\mathrm{N}$ mineralization in the ectorganic layer were of the same order as in the mineral soil. Campylopus introflexus therefore added a successful way of nutrient cycling to the inland dune habitat, by creating a thick ectorganic layer of moss necromass lying on top of the mineral soil, functioning as a sponge, potentially preventing leaching of water and nutrients and therefore supporting the internal nutrient cycling. This way of nutrient cycling is similar to the compact, vertical structure of e.g. Sphagnum bogs (Lang et al. 2009) and reindeer lichens (Cornelissen et al. 2007; Crittenden 1991). Especially the much thicker ectorganic layer in Campylopus is a competitive advantage over the thin layer in most lichen species.

Lichen and grass dominated stages are usually the oldest stages of pioneer vegetation in inland dunes (Sparrius 2011). In lichens, an important part of the $\mathrm{N}$ cycling takes place in a very thin ectorganic basal layer of the thalli (Crittenden 1991; Ellis et al. 2005). However, in grass-dominated plots, $\mathrm{N}$ mineralization in the mineral soil is generally lower than in lichenrich vegetation. This can be explained by the composition of the soil, mainly consisting of fine roots, leading to an increase of the $\mathrm{C}: \mathrm{N}$ ratio (Table 2). Although the soil C:N ratio in the grass stage is similar to the Polytrichum stage, stocks of soil organic matter are much larger due to the deeper solum and plant growth increased, resulting in a higher $\mathrm{N}$ mineralisation in the grass stage.

$\mathrm{N}$ mineralization and $\mathrm{N}$ deposition

Atmospheric $\mathrm{N}$ deposition may elevate levels of plant-available $\mathrm{N}$ and $\mathrm{N}$ content of microorganisms in a direct way. However, $\mathrm{N}$ deposition may also increase $\mathrm{N}$ availability indirectly by creating a more efficient $\mathrm{N}$ mineralization in high $\mathrm{N}$ deposition areas, i.e. by making the microbial community more $\mathrm{C}$ limited. In sites with elevated $\mathrm{N}$ deposition, $\mathrm{N}$ availability in the soil is higher, causing a change in the $\mathrm{N}$ concentration, $\mathrm{N}: \mathrm{P}$ and $\mathrm{C}: \mathrm{N}$ ratios in the vegetation. This change has been demonstrated in a fertilization experiment in inland dune vegetations (Sparrius 2011). Decomposition of litter, moss rhizoids and grass roots with low $\mathrm{C}: \mathrm{N}$ ratios may thus yield higher amounts of $\mathrm{N}$ for each decomposing unit of $\mathrm{C}$, making the $\mathrm{N}$ mineralization more efficient and also affect the C:N and $\mathrm{N}: \mathrm{P}$ ratios of soil microbial biomass (Swift et al. 1979).

A paradox was found for the amount of microbial biomass, which surprisingly decreased with increasing $\mathrm{N}$ deposition, although net $\mathrm{N}$ mineralisation was higher. As a result, in Wekerom, $\mathrm{N}$ mineralization per unit microbial $\mathrm{C}$ was twice as high as in Aekinge. This suggests a surplus in microbial $\mathrm{N}$, demonstrated by the lower microbial $\mathrm{C}: \mathrm{N}$ ratio (Table 4), and saturation of the soil with $\mathrm{N}$ compounds (Fig. 2) in the high $\mathrm{N}$ deposition site, even though the $\mathrm{C}: \mathrm{N}$ ratio of the soil was not different between the high and low $\mathrm{N}$ deposition 
sites (Table 2). Also, respiration rates were found to be rather similar in both sites, which suggests that micro-organisms were actually more active in the high-deposition area. Similar results, i.e. low amounts of micro-organisms in soils with high $\mathrm{N}$ availability, have been found in previous studies in forest ecosystems (Berg 1988; Wallenstein 2003; Wallenstein et al. 2006). The mechanism behind these observations is unclear, but it shows that elevated levels of $\mathrm{N}$ deposition may lead to deviating microbial communities adapted to a high $\mathrm{N}$ environment.

The ectorganic layer of Campylopus introflexus

Apart from a generic increase in succession rate, the moss species Campylopus introflexus is invasive in sites with high $\mathrm{N}$ deposition or on bare soil rich in organic matter, outcompeting the original lichen vegetation (Sparrius and Kooijman 2011). The formation of a thick ectorganic layer in the moss carpets facilitates the water holding capacity, interception of deposited nutrients, $\mathrm{N}$ mineralization and uptake of mineralized compounds in the upper, living parts of the moss mat (Sparrius and Kooijman 2011). It is not completely clear why $C$. introflexus is unsuccessful in low $\mathrm{N}$ deposition sites. However, it is possible that in the absence of excess nitrogen, basal decomposition of the ectorganic layer is faster than apical growth, making the moss mat thinner. The apical, living part of the moss mat is only a few mm thick. Without a robust ectorganic layer, the moss mat is easily overgrown by grasses and lichens (Sparrius 2011). This mechanism might be a topic for future studies.

\section{Relevance for nature conservation}

Nitrogen deposition is one of the major threats to nutrient-poor habitats such as drift sands (e.g. Bobbink et al. 2010). The results showed that in all succession stages $\mathrm{N}$ mineralization and $\mathrm{N}$ availability significantly increased in the high $\mathrm{N}$ deposition site. As vegetation growth is mostly $\mathrm{N}$ limited, $\mathrm{N}$ deposition is likely to cause an increase in succession rate. Therefore, reduction of $\mathrm{N}$ deposition should be one of the most important measures to conserve the drift sand habitat.

In the high $\mathrm{N}$ deposition area where $\mathrm{N}$ availability is high, competitive species, initially $C$. introflexus and later grasses are likely to start dominating the vegetation on such soils (Sparrius and Kooijman 2011).

\section{Conclusions}

During drift sand succession, soil organic matter accumulates, accompanied by a decreasing $\mathrm{pH}$, increasing microbial biomass, respiration, net $\mathrm{N}$ mineralization and nitrification. Mats of Polytrichum piliferum formed an exception, as this was the only succession stage where net $\mathrm{N}$ mineralization was low or even negative, which supports that early succession in drift sands is $\mathrm{N}$ limited, even in areas with high $\mathrm{N}$ deposition. In later succession stages, the ectorganic layer of Campylopus introflexus and lichens played an important role in $\mathrm{N}$ cycling, presumably facilitating uptake of the mineralized compounds by the living part of the plant.

Atmospheric $\mathrm{N}$ deposition (mainly as ammonia) caused a decrease in microbial biomass, but led to higher net $\mathrm{N}$ mineralization, especially per unit microbial C. Differences between microbial C:N and N:P ratios supported that micro-organisms in sites with high $\mathrm{N}$ deposition were not $\mathrm{N}$ limited. As a result, $\mathrm{N}$ deposition leads to higher $\mathrm{N}$ availability in the form of ammonium and nitrate for plants in both direct and indirect ways. Elevated $\mathrm{N}$ deposition leads to higher $\mathrm{N}$ availability which may cause accelerated succession.

Acknowledgements We wish to thank Prof. Jan Sevink and Prof. Leo Stroosnijder and two anonymous referees for commenting on this manuscript, Leo Hoitinga, Leen de Lange, Piet Wartenbergh and Ton van Wijk for laboratory assistance and Marijn Nijssen for help with the monthly sampling of ammonia diffusion tubes. The project was financially supported by the OBN program of the Dutch Ministry of Economic Affairs, Agriculture and Innovation.

Open Access This article is distributed under the terms of the Creative Commons Attribution License which permits any use, distribution, and reproduction in any medium, provided the original author(s) and the source are credited.

\section{References}

Aptroot A, van Herk CM, Sparrius LB, Spier JL (2004) Checklist van de Nederlandse korstmossen en korstmosparasieten. Buxbaumiella 69:17-55

Berendse F (1990) Organic-matter accumulation and nitrogen mineralization during secondary succession in heathland ecosystems. J Ecol 78:413-427

Berendse F (1998) Effects of dominant plant species on soils during succession in nutrient-poor ecosystems. Biogeochemistry $42: 73-88$ 
Berg B (1988) Dynamics of nitrogen N-15 in decomposing Scots pine (Pinus sylvestris) needle litter: long-term decomposition in a Scots pine forest. Can J Bot 66:1539-1546

Bobbink R, Hornung M, Roelofs JGM (1998) The effects of airborne nitrogen pollutants on species diversity in natural and semi-natural European vegetation. J Ecol 86:738

Bobbink R, Hicks K, Galloway J, Spranger T, Alkemade R, Ashmore M, Bustamante M, Cinderby S, Davidson E, Dentener F, Emmett BA, Erisman J-W, Fenn ME, Gilliam F, Nordin A, Pardo L, de Vries W (2010) Global assessment of nitrogen deposition effects on terrestrial plant diversity: a synthesis. Ecol Appl 20:30-59

Bowden RD (1991) Inputs, outputs and accumulation of nitrogen in an early successional moss (Polytrichum) ecosystem. Ecol Monogr 61:207-223

Brookes PC, Powlson DS, Jenkinson DS (1982) Measurement of microbial biomass phosphorus in soil. Soil Biol Biochem 14:319-329

Brookes PC, Landman A, Pruden G, Jenkinson DS (1985) Chloroform fumigation and the release of soil nitrogen: a rapid direct extraction method to measure microbial biomass nitrogen in soil. Soil Biol Biochem 17:837-842

Cape JN, van der Eerden LJ, Sheppard LJ, Leith ID, Sutton MA (2009) Reassessment of critical levels for atmospheric ammonia. In: Sutton MA, Reis S, Baker SMH (eds) Atmospheric ammonia: detecting emission changes and environmental impacts. Results of an expert workshop under the convention on long-range transboundary air pollution. Springer, Berlin, pp 15-40

Cornelissen JHC, Callaghan TV, Alatalo JM, Michelsen A, Graglia E, Hartley AE, Hik DS, Hobbie SE, Press MC, Robinson CH, Henry GHR, Shaver GR, Phoenix GK, Jones DG, Jonasson S, Chapin FS III, Molau U, Neill C, Lee JA, Melillo JM, Sveinbjörnsson B, Aerts R (2001) Global change and arctic ecosystems: is lichen decline a function of increases in vascular plant biomass? J Ecol 89:984-994

Cornelissen JHC, Lang SI, Soudzilovskaia NA, During HJ (2007) Comparitive cryptogam ecology: a review of bryophyte and lichen traits that drive biogeochemistry. Ann Bot 99:987-1001

Crittenden PD (1991) Ecological significance of necromass production in mat-forming lichens. Lichenologist 23:323331

Crocker RL, Major J (1955) Soil development in relation to vegetation and surface age at Glacier Bay, Alaska. J Ecol 43:427-448

de Haan BJ, Kros J, Bobbink R, van Jaarsveld JA, de Vries W, Noordijk H (2008) Ammoniak in Nederland. Rijksinstituut voor Volksgezondheid en Milieu, Bilthoven

Eerens HC, van Dam JD (eds) (2001) Grootschalige luchtverontreiniging en depositie in de Nationale Milieuverkenning 5. Rapport 408129016. Rijksinstituut voor Volksgezondheid en Milieu, Bilthoven

Ellis CJ, Crittenden PD, Scrimgeour CM, Ashcroft CJ (2005) Translocation of N-15 indicates nitrogen recycling in the mat-forming lichen Cladonia portentosa. New Phytol 168:423-433

Gerlach A, Albers EA, Broedlin W (1994) Development of the nitrogen-cycle in the soils of a coastal dune succession. Acta Bot Neerl 43:189-203
Hasse T (2005) Charakterisierung der Sukzessionsstadien im Spergulo-Corynephoretum (Silbergrasfluren) unter besonderer Berücksichtigung der Flechten. Tuexenia 25:407424

Hassel K, Söderström L (2005) The expansion of the alien mosses Orthodontium lineare and Campylopus introflexus in Britain and continental Europe. J Hattori Bot Lab 97:183-193

Keeney DR (1980) Prediction of soil nitrogen availability in forest ecosystems: a literature review. For Sci 26:159171

Kooijman AM, Kooijman-Schouten MM, Martinez-Hernandez GB (2008) Alternative strategies to sustain N-fertility in acid and calcaric beech forests: low microbial N-demand versus high biological activity. Basic Appl Ecol 9:410421

Lang SI, Cornelissen JHC, Klahn T, van Logtestijn RSP, Broekman R, Schweikert W, Aerts R (2009) An experimental comparison of chemical traits and litter decomposition rates in a diverse range of subarctic bryophyte, lichen and vascular plant species. J Ecol 97:886-900

Nijssen M, Riksen MPJM, Sparrius LB, Bijlsma RJ, van den Burg A, van Dobben HF, Jungerius PD, Ketner-Oostra HGM, Kooijman AM, Kuiters AL, van Swaay C, van Turnhout C, de Waal R (2011) Effectgerichte maatregelen voor het herstel en beheer van stuifzanden. OBN stuifzandonderzoek 20062010. Directie Kennis en Innovatie, Ministerie van Economische Zaken, Landbouw en Innovatie, Den Haag

Schulze ED, Schulze W, Kelliher FM, Vygodskaya NN, Ziegler W, Kobak KI, Koch H, Arneth A, Kusnetsova WA, Sogatchev A, Issajev A, Bauer G, Hollinger DY (1995) Aboveground biomass and nitrogen nutrition in a chronosequence of pristine Dahurian Larix stands in Eastern Siberia. Can J For Res 25:943-960

Siebel HN, During HJ (2006) Beknopte mosflora van Nederland en België. KNNV Uitgeverij, Utrecht

Sipman HJM (1978) De Nederlandse Cladonia's (lichenes). KNNV, Utrecht

Sluijter RJCF, Nellestijn J (2009) KNMI Klimaatatlas van Nederland. Uitgeverij Elmar, Rijswijk

Sparrius LB (2011) Inland dunes in The Netherlands: soil, vegetation, nitrogen deposition and invasive species. Dissertation. University of Amsterdam, Amsterdam

Sparrius LB, Kooijman AM (2011) Invasiveness of Campylopus introflexus in drift sands depends on nitrogen deposition and soil organic matter. Appl Veg Sci 14:221-229

Sparrius LB, Sevink J, Kooijman AM (2012) Effects of nitrogen deposition on soil and vegetation in primary succession stages in inland drift sands. Plant Soil 353:261-272

Swift MJ, Heal OW, Anderson JM (1979) Decomposition in terrestrial ecosystems. University of California Press, Los Angeles

Tietema A (1992) Nitrogen cycling and soil acidification in forest ecosystems in the Netherlands. Dissertation. University of Amsterdam, Amsterdam

van der Meijden R (ed) (2005) Heukels' flora van Nederland, 23rd edn. Wolters-Noordhoff, Groningen

van Jaarsveld JA (2004) The operational priority substances model. Description and validation of OPS-Pro 4.1. Rijksinstituut voor Volksgezondheid en Milieu, Bilthoven 
van Mierlo JEM, Wilms YJC, Berendse F (2000) Effects of soil organic matter and nitrogen supply on competition between Festuca ovina and Deschampsia flexuosa during inland dune succession. Plant Ecol 148:51-59

Wallenstein MD (2003) Effects of nitrogen fertilization on soil microbial communities. Geophys Res Abstr 5:13087
Wallenstein MD, McNulty S, Fernandez IJ, Boggs J, Schlesinger WH (2006) Nitrogen fertilization decreases forest soil fungal and bacterial biomass in three long-term experiments. For Ecol Manag 222:459-468

Westerman RL (1990) Soil testing and plant analysis. Soil Science Society of America, Madison 